\title{
Short-term treatment with nitrate is not sufficient to induce in vivo antithrombotic effects in rats and mice
}

\author{
K. Kramkowski ${ }^{1}$ - A. Leszczynska ${ }^{1}$ - K. Przyborowski $^{2}$ - B. Proniewski ${ }^{2}$. \\ N. Marcinczyk $^{1}$ - U. Rykaczewska ${ }^{1}$ - D. Jarmoc ${ }^{1}$ • E. Chabielska ${ }^{1}$. \\ S. Chlopicki ${ }^{2,3}$
}

Received: 25 May 2016 / Accepted: 27 September 2016/Published online: 14 October 2016

(C) The Author(s) 2016. This article is published with open access at Springerlink.com

\begin{abstract}
In humans, short-term supplementation with nitrate is hypotensive and inhibits platelet aggregation via an nitric oxide (NO)-dependent mechanism. In the present work, we analyzed whether short-term treatment with nitrate induces antithrombotic effects in rats and mice. Arterial thrombosis was evoked electrically in a rat model in which renovascular hypertension was induced by partial ligation of the left renal artery. In mice expressing green fluorescent protein, laserinduced thrombosis was analyzed intravitally by using confocal microscope. Sodium nitrate $\left(\mathrm{NaNO}_{3}\right)$ or sodium nitrite $\left(\mathrm{NaNO}_{2}\right)$ was administered orally at a dose of $0.17 \mathrm{mmol} /$ $\mathrm{kg}$, twice per day for 3 days. Short-term nitrate treatment did not modify thrombus formation in either rats or mice, while nitrite administration led to pronounced antithrombotic activity. In hypertensive rats, nitrite treatment resulted in a significant decrease in thrombus weight $(0.50 \pm 0.08 \mathrm{mg}$ vs. VEH $0.96 \pm 0.09 \mathrm{mg} ; p<0.01)$. In addition, nitrite inhibited ex vivo platelet aggregation and thromboxane $\mathrm{B}_{2}\left(\mathrm{TxB}_{2}\right)$ generation and prolonged prothrombin time. These effects were accompanied by significant increases in blood NOHb concentration and plasma nitrite concentration. In contrast, nitrate did not affect ex vivo platelet aggregation or prothrombin time and led to only slightly elevated nitrite plasma concentration. In mice, nitrate was also ineffective, while nitrite led to decreased
\end{abstract}

S. Chlopicki

stefan.chlopicki@jcet.eu

1 Department of Biopharmacy, Medical University of Bialystok, Mickiewicza 2C Str, 15-222 Bialystok, Poland

2 Jagiellonian Centre of Experimental Therapeutics (JCET), Jagiellonian University, Bobrzynskiego 14, 30-348 Krakow, Poland

3 Chair of Pharmacology, Jagiellonian University Medical College, Grzegórzecka 16, 31-531 Krakow, Poland platelet accumulation in the area of laser-induced endothelial injury. In conclusion, although nitrite induced profound NOdependent antithrombotic effects in vivo, conversion of nitrates to nitrite in rats and mice over short-term 3-day treatment was not sufficient to elicit NO-dependent antiplatelet or antithrombotic effects.

Keywords Nitrate $\cdot$ Nitrite $\cdot$ Nitric oxide $\cdot$ Thrombosis . Platelet

\section{Introduction}

For decades, nitrites $\left(\mathrm{NO}_{2}^{-}\right)$and nitrates $\left(\mathrm{NO}_{3}{ }^{-}\right)$were thought to be stable end-products of nitric oxide (NO) produced by NO synthase (NOS) (Bryan 2006). Recently, however, a reductive $\mathrm{NO}_{3}{ }^{-}-\mathrm{NO}_{2}{ }^{-}-\mathrm{NO}$ pathway has been proposed as a backup system that acts to maintain NO generation (Kapil 2013).

Compatible with the importance of the reductive pathway for NO production in vivo, even short-term (3 days) supplementation with $\mathrm{NaNO}_{3}(0.1 \mathrm{mmol} / \mathrm{kg}$ daily $)$ was shown to result in a significant increase in plasma $\mathrm{NO}_{2}{ }^{-}$concentration in healthy humans and a subsequent fall in diastolic blood pressure (Larsen 2006). Similarly, short-term (3 days) supplementation with dietary nitrate, given in the form of beetroot juice to healthy volunteers, not only reduced systolic and diastolic blood pressure but also improved endothelial function and significantly attenuated ex vivo collagen-induced and ADP-induced platelet aggregation (Webb 2008). Nitrateinduced effects on blood pressure and platelet aggregation were correlated with an increase in plasma nitrite concentration. Furthermore, Kapil et al. (2010) demonstrated that inorganic nitrate given as a single dose (12 or $24 \mathrm{mmol})$ or in one shot of beetroot juice (containing $5.5 \mathrm{mmol}$ of nitrate) lowered 
blood pressure. This effect was associated with a dosedependent elevation in plasma nitrite concentration as well as elevated cyclic guanosine monophosphate (cGMP), confirming that the acute nitrate effect in humans is mediated by the NO-cGMP pathway (Kapil 2010). Obviously, not only short-term but also long-term intake of inorganic NO supplements was shown to have beneficial effects on the cardiovascular system of humans (Zand 2011).

An overwhelming body of evidence suggests that the beneficial effects of nitrate in humans, either upon shortterm or long-term treatment (Zand 2011; Mills 2016), involve the enterosalivary nitrate-nitrite-NO pathway. Indeed, it has been reported that ingested nitrate is actively transported from blood to the salivary glands and accumulates in saliva (Tannenbaum 1976; Spiegelhalder 1976; Kortboyer 1994; Qin 2012). Oral bacteria reduces nitrate into nitrite (Tannenbaum 1974; Ishiwata 1975; Duncan 1995; Doel 2005; Kapil 2010), which is swallowed and then absorbed in the intestines, resulting in elevated plasma nitrite concentration (Lundberg 2004; Webb 2008; Kapil 2010; Qin 2012). As reviewed by Lundberg and Weitzberg (2010), nitrate-nitrite conversion in the human oral cavity is metabolized by specific reductase enzymes of the commensal bacteria, whereas nitriteNO reduction is enhanced by vitamin $\mathrm{C}$, polyphenols, and cytochrome P450 enzymes. Furthermore, a number of mammalian nitrite reductase enzymes have been demonstrated to reduce nitrite to NO, including xanthine oxidoreductase (XOR) (Cantu-Medellin 2013a,b), hemoglobin (Hb) (Huang 2005; Larsen 2011; Kahn 2013), mioglobin (Mb) (Hendgen-Cotta 2014), neuroglobin ( $\mathrm{Ngb}$ ) (Jayaraman 2011), aldehyde oxidase (AO) (Li 2009), sulfite oxidase (SO) (Wang 2010), components of the mitochondrial electron transport chain (ETC), and NOS (Sparacino-Watkins 2014).

Altogether, the evidence suggests that two important pathways exist for $\mathrm{NO}$ generation: the first from endogenous Larginine, involving NO synthase, and the other involving the reduction of nitrate to nitrite that seems to operate particularly in the context of endothelial dysfunction or hypoxia/low $\mathrm{pH}$.

A number of reports have suggested that the beneficial pharmacological effects of nitrate also pertain to rats and mice (Bouaziz-Keteta 2014; Jiang 2014; Carlström 2015; Roberts 2015). However, it remains unclear whether the reductive nitrate-nitrite-NO pathway is as effective in laboratory rodents as it is in humans and whether NO-mediated effects will be seen after short-term treatment, as in humans (Larsen 2006). To explore this question, we comprehensively analyzed the antithrombotic and antiplatelet effects of nitrate as compared to nitrite and analyzed the conversion of nitrate to nitrite in rats after 3-day treatment. We also tested the antithrombotic effects of 3-day treatment with nitrate, as compared with nitrate, in mice.

\section{Materials and methods}

\section{Animals and the induction of renovascular hypertension}

Male Wistar rats were purchased from Charles River Laboratory and housed in the animal house of the Jagiellonian Centre for Experimental Therapeutics (JCET), Jagiellonian University (Krakow, Poland), under a 12-h light/dark cycle. The animals were grouped in cages as appropriate and had access to sterilized tap water and standard rat chow ad libitum. Green fluorescent protein (GFP)-expressing transgenic mice, based on the C57BL/6J strain (GFP mice) (Okabe 1997), were purchased from the Centre for Experimental Medicine in Bialystok. All procedures involving animals were approved by a bioethics committee and conducted in accordance with the institutional guidelines, which are in compliance with national and international laws, including EU Directive 2010/63/EU for animal experiments and the Guidelines for the Care and the Use of Animals in Biomedical Research (Giles 1987).

The rats were anesthetized with pentobarbital $(40 \mathrm{mg} / \mathrm{kg}$, i.p.). Two-kidney one-clip (2K1C) renovascular hypertension was induced by partial, standardized clipping of the left renal artery (Huang 1981). Six weeks following induction of hypertension, mean blood pressure (MBP) was measured by using the "tail-cuff" method (Panlab, Harvard Apparatus, UE) (Zatz 1990). All rats with elevated blood pressure (SBP/DBP $>140 /$ $90 \mathrm{mmHg}$ ) were assigned to the hypertensive group. Shamoperated (SO) rats served as the control for $2 \mathrm{~K} 1 \mathrm{C}$ hypertensive rats. They underwent the same surgical intervention without clipping of the renal artery. Hypertensive rats were divided into groups undergoing experimentally induced arterial thrombosis in vitro experiments.

\section{Rat model of arterial thrombosis in vivo}

The $2 \mathrm{~K} 1 \mathrm{C}$ rats were anaesthetized with pentobarbital $(40 \mathrm{mg} / \mathrm{kg}$, i.p.) and placed in a supine position on a heated $\left(37^{\circ} \mathrm{C}\right)$ operating table. Arterial thrombosis was induced by electrical stimulation of the right common carotid artery, as previously described (Kramkowski 2012). Briefly, the anode, a stainless steel L-shaped wire, was inserted under the artery and connected to a constant current generator. The cathode was attached subcutaneously to the hindlimb. The artery was stimulated $(1 \mathrm{~mA})$ for $10 \mathrm{~min}$. Fifty-five minutes after the beginning of stimulation, the segment of the common carotid artery containing the formed thrombus was dissected and opened lengthwise, and the thrombus was completely removed and air-dried at room temperature for $24 \mathrm{~h}$. It was then weighed in a blinded manner. 


\section{Platelet aggregation}

Collagen-stimulated platelet aggregation in citrated whole blood was evaluated by using the impedance method, as described previously (Kramkowski 2012), and measured in a whole blood lumi-aggregometer (Chrono-log, USA). Briefly, blood samples were collected from nitrate-treated or nitritetreated $2 \mathrm{~K} 1 \mathrm{C}$ rats with electrically stimulated thrombosis. Samples were collected in $3.13 \%$ trisodium citrate at a volume ratio of 10:1. After 15 -min incubation at $37{ }^{\circ} \mathrm{C}$ with $0.9 \% \mathrm{NaCl}$ (volume ratio $1: 1)$, collagen $(5 \mu \mathrm{g} / \mathrm{ml}$ ) was added. In all aggregation experiments, changes in resistance were registered for $6 \mathrm{~min}$. The extension of the aggregation curve at 6 min was expressed as a percentage of the control response.

\section{Dynamic thromboxane $B_{2}$ generation}

Citrated blood samples from $2 \mathrm{~K} 1 \mathrm{C}$ rats with electrically stimulated thrombosis were diluted with $0.9 \% \mathrm{NaCl}$ at a ratio of $1: 1$ and stirred in aggregation cuvettes at $37^{\circ} \mathrm{C}$ at $1000 \mathrm{rpm}$. At $0,20,40$, and $60 \mathrm{~min}$, samples of stirred blood were drawn off and mixed with a cold solution of acetylsalicylic acid (final concentration $500 \mu \mathrm{M}$ ) at a ratio of $1: 1$. Thromboxane $\mathrm{B}_{2}$ $\left(\mathrm{TxB}_{2}\right)$ concentrations in the obtained samples were determined by ELISA, according to the instructions provided by the kit manufacturer.

\section{Measurement of nitrite, nitrate, and nitrosyl hemoglobin in blood}

Plasma concentrations of nitrite and nitrate were measured with the nitrate/nitrite analysis system, ENO-20 (Eicom). ENO-20 employs liquid chromatography with post-column derivatization by using the Griess reagent. Nitrite and nitrate were separated from other substances in matrix on NO-PAK columns $(4.6 \times 50 \mathrm{~mm}$, Eicom). Nitrate was reduced to nitrite on a cadmium-copper column (NO-RED, Eicom). Nitrite was mixed with the Griess reagent to form a purple azo dye in a reaction coil placed in a column oven at $35^{\circ} \mathrm{C}$, and the absorbance of the dye product was measured at $540 \mathrm{~nm}$. The flow of the mobile phase (Carrier solution, Eicom) was $0.33 \mathrm{ml} /$ $\min$. The Griess reagent was delivered by pump at a rate of $0.11 \mathrm{ml} / \mathrm{min}$. The plasma sample was precipitated with methanol at a ratio of $1: 1(v / v)$. Plasma samples were centrifuged at $10,000 \times \mathrm{g}$ for $10 \mathrm{~min}$. Ten microliters of supernatant was injected into the HPLC system.

The concentration of nitrosyl hemoglobin was measured by electron paramagnetic resonance (EPR). EPR spectra of isolated erythrocytes (snap-frozen isolated erythrocytes obtained from whole blood via centrifugation at $1000 \times g$ and $4{ }^{\circ} \mathrm{C}$ for $5 \mathrm{~min}$ ) were recorded in liquid nitrogen $(77 \mathrm{~K})$ by using a Bruker EMX Plus spectrometer operating at X-band, with a
1041HS resonator. The following conditions were used: microwave power $=15.89 \mathrm{~mW}$, time constant $=81.92 \mathrm{~ms}$, modulation frequency $=100 \mathrm{kHz}$, modulation amplitude $=5 G$, scan time $=20.48 \mathrm{~s}$, scan width $=200 G$, and temperature $=77 \mathrm{~K}$. For each sample, 30 individual scans were averaged. The level of microwave power was determined from the saturation curve of the EPR signal at the centerline of $\mathrm{NOHb}$, which indicated that the signal was not saturated up to approximately to the level of $16 \mathrm{~mW}$. The overlying free radical signals at $G=2$ were quantified experimentally and deconvoluted to enhance $\mathrm{NOHb}$ signal enhance by using an in-house algebraic process. $\mathrm{NOHb}$ levels were expressed as EPR amplitude in arbitrary units, normalized to sample weight $(259.6 \pm 8.8 \mathrm{mg})$.

\section{Measurement of coagulation and fibrinolysis parameters in plasma and blood cell count}

Prothrombin time (PT), activated partial thromboplastin time (aPTT), and fibrinogen (Fg) levels (Clauss method) were determined according to the kit manufacturer's instructions by using the Coag-Chrom 3003 apparatus (Bio-ksel, Poland). For fibrin generation, we used a method described previously ( $\mathrm{He}$ 2001) and modified by us (Buczko 2003). Briefly, fibrin generation curves were created by recalcinating rat plasma samples directly in microplate wells by using $\mathrm{CaCl}_{2}(36 \mathrm{mM})$ dissolved in Tris buffer $(66 \mathrm{mM}$ Tris, $130 \mathrm{mM} \mathrm{NaCl}, \mathrm{pH}$ 7.4) at $37^{\circ} \mathrm{C}$. Increases in optical density in the wells (as a result of fibrin generation) were measured with the microplate reader (Biotec EL808, USA) at 1-min intervals for 9 min and expressed as the area under the curve (AUC). Time-point analysis results were calculated as percentages of basal optical density.

Blood cell count was assessed with an Animal Blood Counter (ABC Vet, Horiba, Germany) in blood collected from the left ventricles of $2 \mathrm{~K} 1 \mathrm{C}$ hypertensive rats after thrombus removal (ex vivo) or untreated $2 \mathrm{~K} 1 \mathrm{C}$ rats (in vitro experiments).

\section{Intravital imaging of platelet accumulation after laser injury of endothelium in mice}

GFP mice were anesthetized with ketamine and xylazine (i.p.). A midline laparotomy incision was made, and then, the mesentery of the ileum was pulled out of the abdomen and draped over a plastic mound. The mesentery was continuously perfused with $37{ }^{\circ} \mathrm{C}$-warmed phosphate-buffered saline (PBS) to prevent the vessels from drying. Mesenteric venules were identified, and endothelial injury was induced by a $514-\mathrm{nm}$ argon-ion laser (Intelligent Imaging Innovations $\mathrm{GmbH}$, Germany). The laser beam was aimed at the endothelium through the microscope objective lens, and the intensity of laser illumination and duration was kept constant (Falati 
2002; Hayashi 2008). Changes in fluorescence intensity were measured automatically by using Slidebook 5.0 software. The fluorescence intensity of GFP was normalized to the initial value in each experiment, and then, areas under the curves were calculated for statistics (Intelligent Imaging Innovations GmbH, Germany) (Falati 2002; Hayashi 2008).

\section{Administration of $\mathrm{NaNO}_{2}$ and $\mathrm{NaNO}_{3}$}

Rats and mice received nitrate or nitrite $(0.17 \mathrm{mmol} / \mathrm{kg})$ twice daily for 3 days (by intragastric gavage); the final dose was given $20 \mathrm{~min}$ before anesthesia. Sterilized tap water $(2 \mathrm{ml} / \mathrm{kg})$ served as a control and vehicle (VEH). The doses of nitrites and nitrates were chosen on the basis of our earlier experiments, which showed that nitrite at a dose of $0.17 \mathrm{mmol}$ is a potent, antithrombotic agent with only weak hemodynamic effects (Kramkowski 2015).

\section{Chemicals and drugs}

The following agents were used: sodium nitrite $\left(\mathrm{NaNO}_{2}\right)$, sodium nitrate $\left(\mathrm{NaNO}_{3}\right)$, calcium chloride $\left(\mathrm{CaCl}_{2}\right)$, sodium chloride $(\mathrm{NaCl})$, and Tris buffer (all Sigma-Aldrich, Germany); pentobarbital (Morbital) from Biovet (Poland); PBS from Biomed (Poland); collagen from Chrono-log (USA); readyto-use kits for blood cell count from HoribaABX (Germany); oxymetric tests from Ultra Nova Biomedical (USA); routine laboratory reagents for determining PT, aPTT, and Fg levels in rat plasma from HemosIL Instrumentation Laboratory (USA); rat PAI-1 and tissue tPA ELISA kits from Hyphen BioMed (France); and a $\mathrm{TxB}_{2}$ ELISA kit from ENZO Life Science. All other products were purchased from Sigma (Gillingham, Dorset, UK).

\section{Statistical analysis}

We used analysis of variance (ANOVA), a multiple comparison test (for normal distribution), and a Bonferroni correction for multiple comparisons after a nonparametric test (for nonnormal distribution). A $p$ value $<0.05$ was considered to indicate significance.

\section{Results}

\section{Effects of nitrate and nitrite on thrombus weight in rat}

Treatment with nitrate $(n=9)$ at a dose of $0.17 \mathrm{mmol} / \mathrm{kg}$ twice daily for 3 days (p.o.) did not affect thrombus weight (TW) $(0.83 \pm 0.06 \mathrm{mg}$ vs. VEH $0.96 \pm 0.09 \mathrm{mg}, n=11, \mathrm{~ns})$, while an equimolar dose of nitrite $(n=9)$ decreased TW (TW $=0.50 \pm 0.08 \mathrm{mg}, p<0.01$, vs. VEH) (Fig. 1).

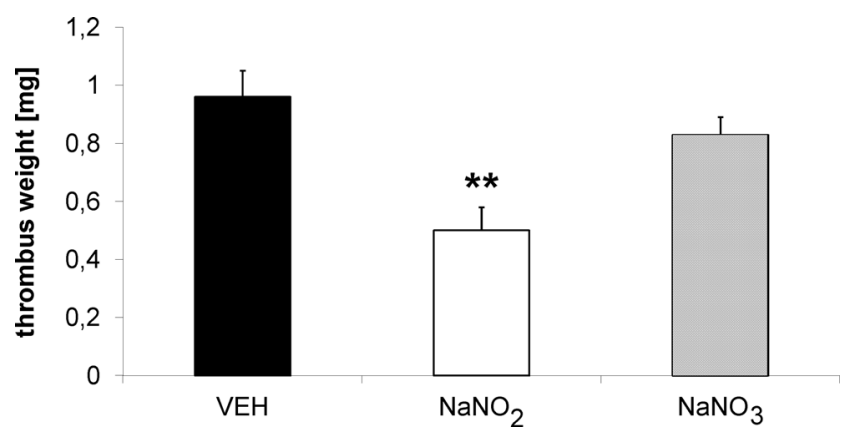

Fig. 1 Lack of antithrombotic effect of nitrate compared to nitrite in hypertensive (2K1C) rats after oral administration twice daily for 3 days $(0.17 \mathrm{mmol} / \mathrm{kg}) ; * *<<0.01 \mathrm{vs}$. VEH

\section{Effects of nitrate and nitrite on ex vivo platelet function}

Treatment with nitrate similarly failed to influence collagenstimulated whole blood ex vivo platelet aggregation $(87.50 \pm 7.14 \%$ vs. VEH $100 \pm 4.46 \%$, ns $)$, while nitrite treatment inhibited platelet aggregation $(70.54 \pm 7.14 \%$ vs. VEH, $p<0.05$ ) (Fig. 2a). Furthermore, nitrate treatment failed to affect ex vivo dynamic generation of $\mathrm{TxB}_{2}$ in full blood assay, while nitrite treatment significantly inhibited generation of $\mathrm{TxB}_{2}$ ( $p<0.05$ vs. VEH) (Fig. 2b).

\section{Effects of nitrate and nitrite treatment on $\mathrm{NOHb}$ and nitrate and nitrite concentrations in blood}

As expected, nitrate plasma concentration was profoundly increased in rats treated with nitrate $(114.45 \pm 6.86 \mu \mathrm{M}$ vs. VEH $13.70 \pm 2.41 \mu \mathrm{M}, p<0.05)$, while $\mathrm{NOHb}$ concentration was only moderately increased $(328 \pm 6.0$ units $/ \mathrm{mg}$ vs. VEH $231.9 \pm 36$ units/mg, ns). In the nitrite-treated group (Fig. 3), nitrite plasma concentration was markedly increased $(43.71 \pm 6.44 \mu \mathrm{M}, p<0.001$, vs. VEH $0.61 \pm 0.11 \mu \mathrm{M})$, as was $\mathrm{NOHb}$ concentration $(27.100 \pm 5514$ units $/ \mathrm{mg}, p<0.001$, vs. VEH $231.9 \pm 36$ units/mg).

\section{Effects on nitrate and nitrite treatment on coagulation and blood cell count}

Nitrate treatment did not influence any of the estimated coagulation parameters, while nitrite decreased fibrin generation $(p<0.05$ and $p<0.01 \mathrm{vs.} \mathrm{VEH} \mathrm{in} \mathrm{point-to-point} \mathrm{analysis} \mathrm{of}$ VEH curve) and decreased area under the curve $\left(88.71 \pm 17.44\right.$ units $^{2}$ vs. VEH $171.94 \pm 15.79$ units $^{2}$, $p<0.05$ ) (Fig. $4 \mathrm{a}, \mathrm{b}$ ). On the other hand, as shown in Table 1, nitrite treatment slightly prolonged PT but did not change other coagulation parameters such as APTT, TT, fibrinogen level, and QUICK. Neither nitrate nor nitrite influenced blood cell count (Table 2). 
Fig. 2 Lack of ex vivo antiplatelet effect of nitrate compared to nitrite: a whole blood collagen-stimulated platelet aggregation and $\mathbf{b}$ dynamic $\mathrm{TxB}_{2}$ generation in hypertensive

$(2 \mathrm{~K} 1 \mathrm{C})$ rats after oral

administration twice daily for

3 days $(0.17 \mathrm{mmol} / \mathrm{kg}) ;{ }^{*} p<0.05$

vs. VEH
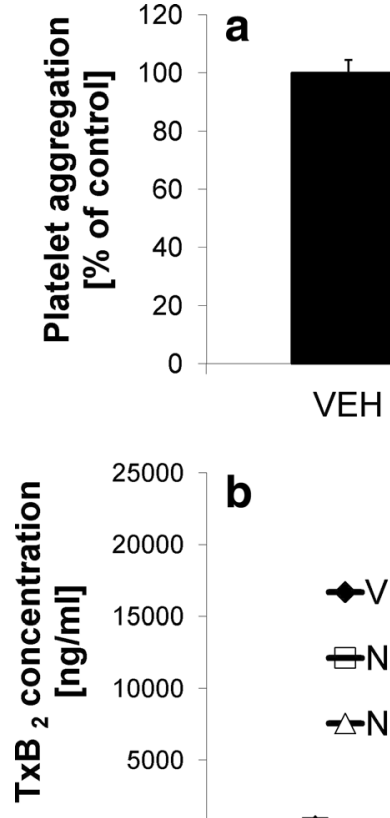

b

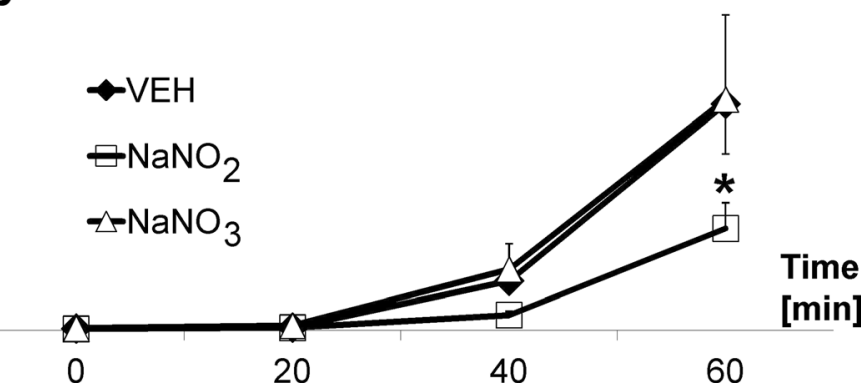

$\left(90.26 \pm 24.45\right.$ units $^{2}$ vs. VEH $95.76 \pm 19.66$ units $^{2}$, ns $)$, while nitrite treatment decreased the AUC in the time-course curve of platelet accumulation $\left(49.03 \pm 6.31\right.$ units $^{2}$ vs. VEH $95.76 \pm 19.66$ units $^{2}, p<0.05$ ) (Figs. 5a, b and $6 \mathrm{a}-\mathrm{c}$ ).
Nitrate treatment did not influence platelet accumulation in the area of the laser-injured endothelium in GFP mice

Effects of nitrate and nitrite treatment on in vivo platelet accumulation in mice: intravital imaging

Fig. 3 Effect of nitrite and nitrate on a nitrite plasma concentration and $\mathbf{b} \mathrm{NOHb}$ content in blood in hypertensive (2K1C) rats (oral administration twice daily for 3 days, $0.17 \mathrm{mmol} / \mathrm{kg}$ ); $* * * p<0.001$ vs. VEH
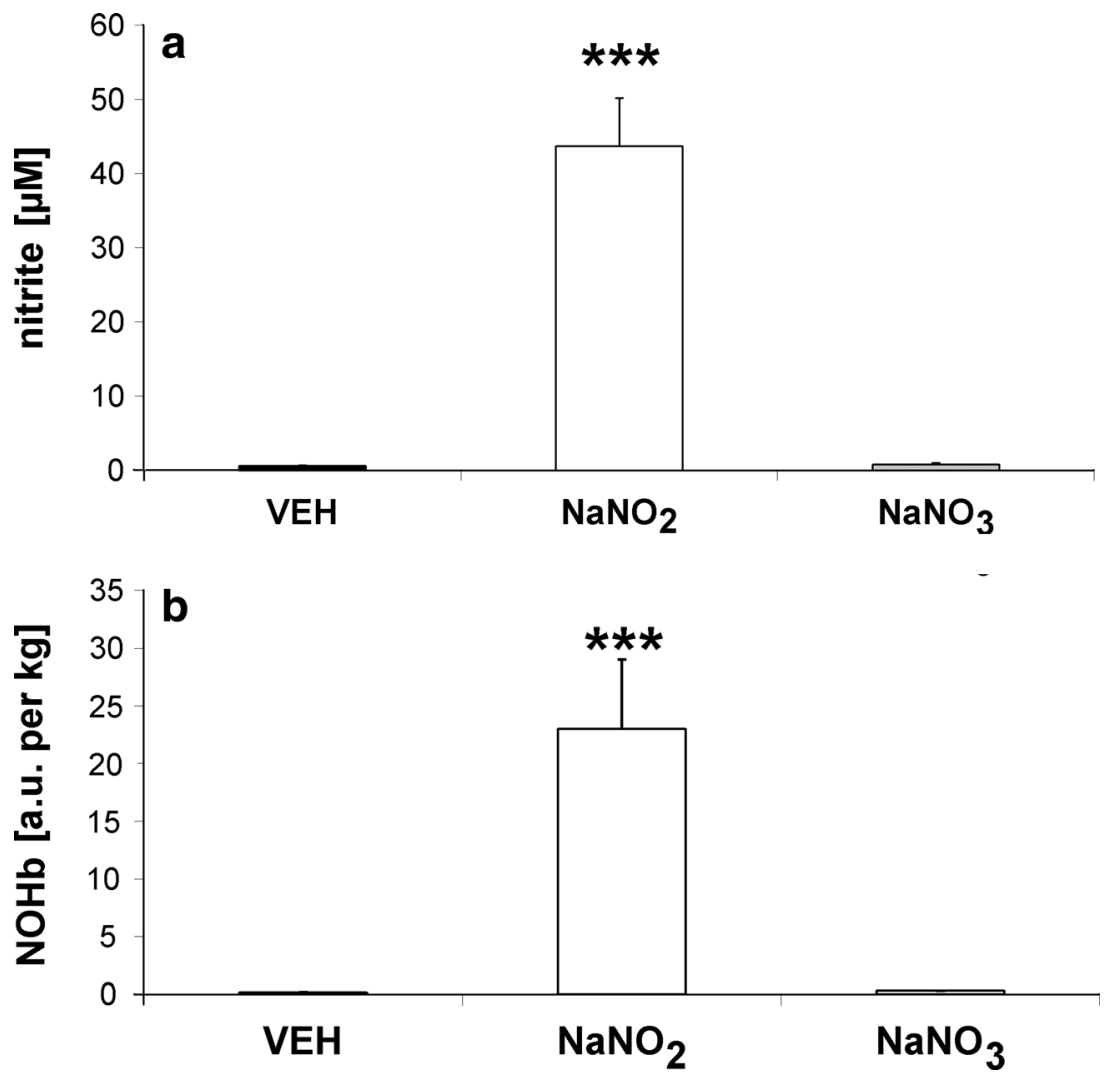
Fig. 4 Ex vivo effects of nitrate and nitrite on a fibrin generation and $\mathbf{b}$ area under the curve (AUC) in hypertensive (2K1C) rats (oral administration twice daily for 3 days, $0.17 \mathrm{mmol} / \mathrm{kg}$ ); ${ }^{*} p<0.05$, $* * p<0.01$ vs. VEH
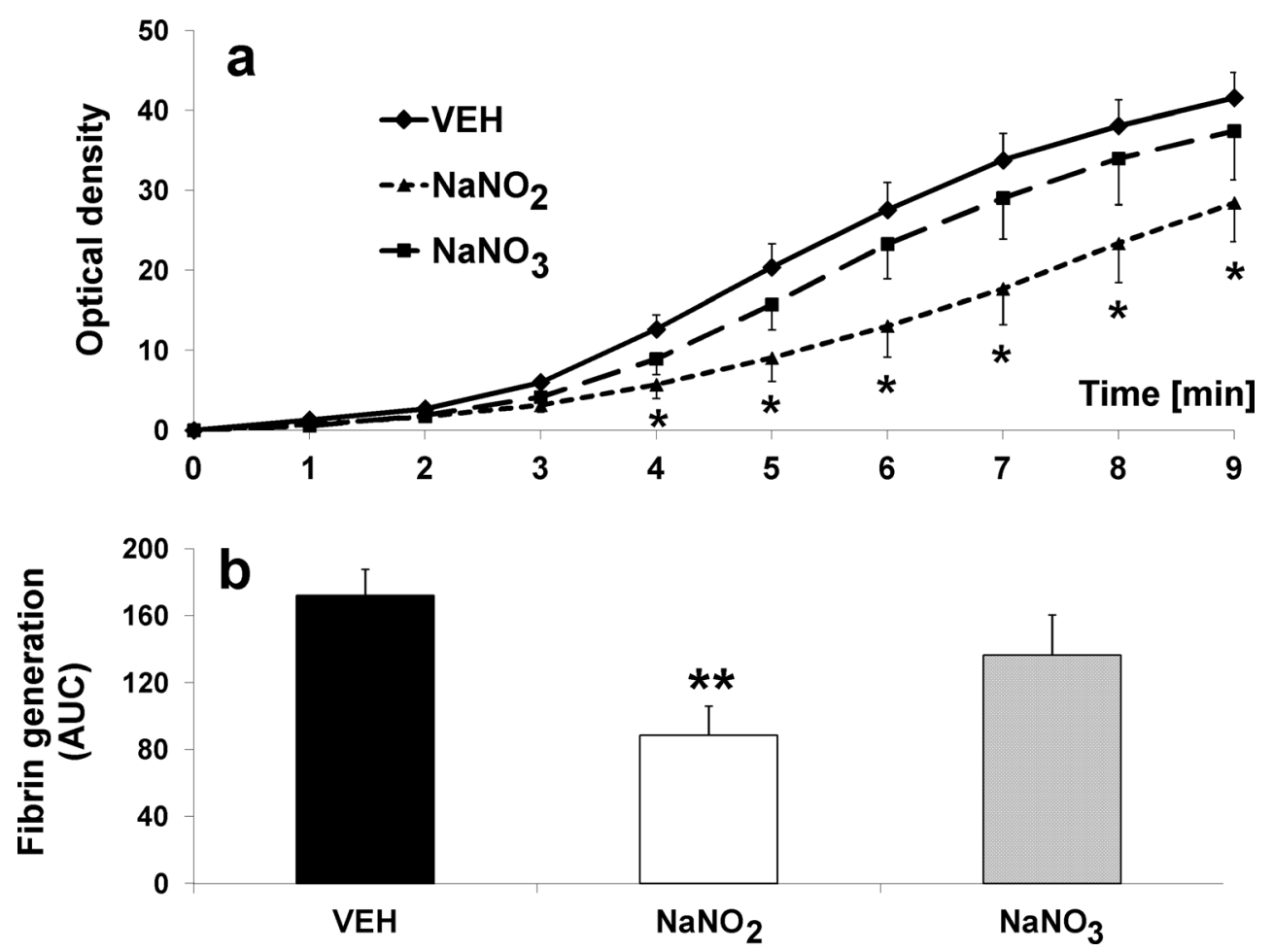

\section{Discussion}

In the present work, we demonstrated for the first time that a low dose of nitrate $(0.17 \mathrm{mmol} / \mathrm{kg}$, p.o., bid $)$, given as a shortterm 3-day treatment, did not display antithrombotic effects in rats and in mice. In contrast, an equimolar dose of nitrite decreased thrombus weight, inhibited ex vivo collagenstimulated platelet aggregation, inhibited platelet $\mathrm{TxB}_{2}$ generation in full blood assay, and inhibited coagulation. Furthermore, we found that nitrite, but not nitrate, decreased fibrin generation. Since the overall coagulation potential depends on active phospholipid surfaces that are exposed by activated platelets, we suggest that nitrite decreases coagulation by an indirect mechanism that is dependent on platelet inhibition, rather than by direct inhibition of clotting factors. Thrombus weight and nitrite plasma concentration correlated with $\mathrm{NOHb}$ content in blood, suggesting involvement of $\mathrm{NO}$ in the antithrombotic effects of nitrite. Similarly, in mice, nitrate was ineffective, while nitrite decreased platelet accumulation in the area of laser-induced endothelial injury. Although the vasodilatory effect of nitrite has been widely studied, the effect of nitrite on platelet activity has received much less attention so far. Nitrite at a high concentration $(500 \mathrm{mM})$ was reported to inhibit ADP-induced platelet aggregation and to increase cyclic guanosine monophosphate (cGMP) (Laustiola 1991), suggesting that the effects of nitrite on platelets are mediated by $\mathrm{NO}$ and the subsequent activation of guanylyl cyclase. The elevation in plasma nitrite levels following the ingestion of a nitrate-rich diet was reported to reduce blood pressure and attenuate the platelet aggregation induced by ADP and collagen in plasma, supporting the importance of nitrite's effects on platelet activity in humans
Table 1 Effects of nitrate and nitrite on clotting parameters in rats

\begin{tabular}{llll}
\hline & VEH (2K1C) & $\begin{array}{c}3 \text { days NaNO2 } 0.17 \\
\mathrm{mmol} / \mathrm{kg}\end{array}$ & $\begin{array}{c}3 \text { days NaNO3 0.17 } \\
\mathrm{mmol} / \mathrm{kg}\end{array}$ \\
\hline PT [s] & $18.1 \pm 0.2$ & $\mathbf{1 9 . 5} \pm \mathbf{0 . 6}$ & $18.6 \pm 0.4$ \\
aPTT [s] & $19.1 \pm 0.4$ & $18.7 \pm 0.6$ & $18.5 \pm 0.7$ \\
Fg [ng/ml] & $2.5 \pm 0.1$ & $2.5 \pm 0.1$ & $2.4 \pm 0.04$ \\
QUICK & $58.6 \pm 2.0$ & $55.0 \pm 4.1$ & $57.5 \pm 2.6$ \\
\hline
\end{tabular}

$P T$ prothrombin time, $A P T T$ activated partial thromboplastin time, $F g$ fibrinogen level, $Q U I C K$ percentage index of prothrombin time (Quick index)

$* p<0.05$ vs. VEH 
Table 2 Effects of nitrate and nitrite on blood cell count in rats

\begin{tabular}{llll}
\hline & VEH (2K1C) & $\begin{array}{l}\mathrm{NaNO}_{2} 3 \text { days } 0.17 \\
\mathrm{mmol} / \mathrm{kg}\end{array}$ & $\begin{array}{l}\mathrm{NaNO}_{3} 3 \text { days } 0.17 \\
\mathrm{mmol} / \mathrm{kg}\end{array}$ \\
\hline $\mathrm{WBC}\left[10^{6} / \mu \mathrm{l}\right]$ & $3.33 \pm 0.18$ & $2.70 \pm 0.19$ & $3.00 \pm 0.35$ \\
$\mathrm{RBC}\left[10^{6} / \mu \mathrm{l}\right]$ & $7.51 \pm 0.2$ & $7.10 \pm 0.27$ & $7.10 \pm 0.10$ \\
$\mathrm{HGB}[\mathrm{g} / \mathrm{dl}]$ & $13.59 \pm 0.35$ & $13.25 \pm 0.4$ & $13.23 \pm 0.27$ \\
$\mathrm{HCT}[\%]$ & $41.58 \pm 1.07$ & $40.00 \pm 1.52$ & $40.68 \pm 1.55$ \\
$\mathrm{MCV}[\mathrm{fl}]$ & $55.42 \pm 0.31$ & $56.33 \pm 0.71$ & $\mathbf{5 7 . 5} \pm \mathbf{0 . 5 0}$ \\
$\mathrm{MCH}[\mathrm{pg}$ per cell] & $18.13 \pm 0.15$ & $18.68 \pm 0.28$ & $18.68 \pm 0.25$ \\
MCHC [g/dl] & $32.68 \pm 0.15$ & $33.17 \pm 0.63$ & $32.60 \pm 0.45$ \\
PLT $\left[10^{3} / \mu \mathrm{ll}\right]$ & $623 \pm 24$ & $650 \pm 31$ & $669 \pm 52$ \\
\hline
\end{tabular}

$W B C$ white blood cells, $R B C$ red blood cells, $H G B$ hemoglobin, $H C T$ hematocrit, $M C V$ mean corpuscular volume, $M C H$ mean corpuscular hemoglobin, $M C H C$ mean corpuscular hemoglobin concentration, PLT platelets
(Webb 2008). In our experiments in rats, we have clearly demonstrated that nitrite inhibits platelets ex vivo, i.e., inhibits collagen-induced platelet aggregation in whole blood, as well as decreases dynamic generation of $\mathrm{TxB}_{2}$. Since arterial thrombosis is strongly platelet-dependent (Kramkowski 2010; Pruolle 2014), our experiments suggest that nitrite's strong antithrombotic effects are mediated in large part by inhibition of platelets. Indeed, using real-time intravital confocal visualization of thrombosis, we observed highly diminished platelet accumulation after laser injury to the endothelium in mice treated with nitrite. In the same model, nitrate was without effect on platelets.

Altogether, our results suggest that nitrite induces profound NO-dependent antithrombotic effects with short-term treatment in vivo. However, the conversion of nitrate to nitrite in rats and mice was not sufficient to elicit NO-dependent antiplatelet and antithrombotic effects over the short-term period of nitrate treatment shown to be effective in humans (Larsen 2006).

Accordingly, effects of nitrite in rats and mice seem to be similar to those described in humans, including antiplatelet effects mediated by NO (Lasrsen 2006; Webb 2008). On the other hand, we did not observe pharmacologically important antiplatelet or antithrombotic effects of nitrate, underscoring the differences in metabolism between nitrate and nitrite in rats and mice, as compared to humans.

In humans, the half-life of an oral dose of inorganic nitrate is surprisingly long, ranging between 5 and $8 \mathrm{~h}$. On the other hand, nitrate is instantly converted to nitrite, so the increase in plasma nitrite concentration parallels the increase in plasma nitrate concentration (Larsen 2011). It was suggested that the increase in nitrite after nitrate administration is entirely due to enterosalivary circulation of nitrate and nitrate's reduction to nitrite by commensal bacteria in the mouth (Lundberg 2010).
Fig. 5 Effects of nitrate and nitrite on a kinetics of platelet accumulation in the area of laserinjured endothelium in GFP mice and $\mathbf{b}$ area under the curve (AUC) (oral administration for twice daily for 3 days, $0.17 \mathrm{mmol} / \mathrm{kg}$ )
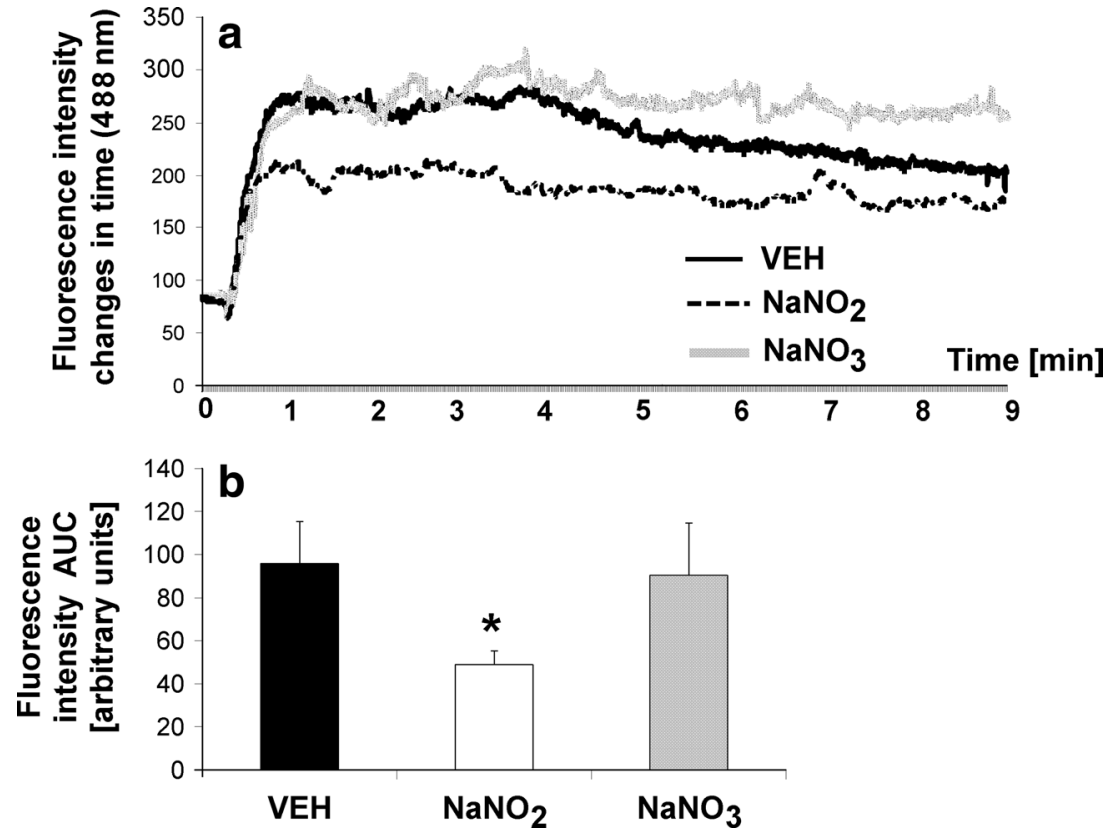

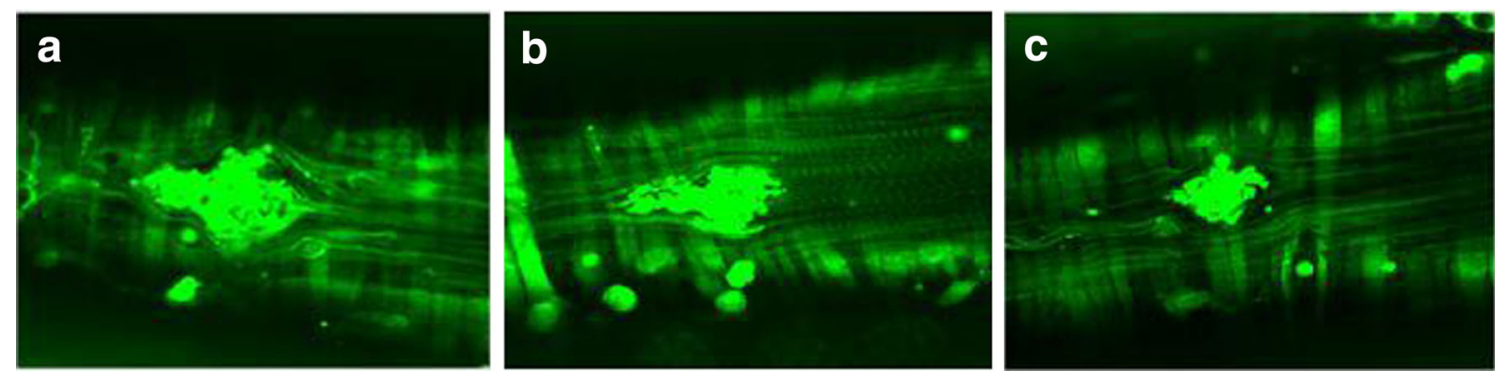

Fig. 6 Representative images of thrombi formed $50 \mathrm{~s}$ after laser induction in a VEH, $\mathbf{b} \mathrm{NaNO}_{3}$ or $\mathbf{c} \mathrm{NaNO}_{2}(0.17 \mathrm{mmol} / \mathrm{kg}$ per os, 3 days $)$ treated GFP mice

In our previous paper, we have demonstrated that XOR was involved in nitrite reduction into NO in rats (Kramkowski 2015). Here, we did not study the mechanism of nitrite reduction, but we believe that XOR could be involved not only in rats but also in mice, as XOR displays substantially higher activity in rodents as compared to human (Cantu-Medellin $2013 \mathrm{a}, \mathrm{b})$. On the other hand, unlike in vitro hypoxic condition (Millar 1998), it is unlikely that XOR contributed to nitrate reduction as the conversion of nitrate to nitrite was minimal either in rats or in mice.

In our study, we administered sodium nitrate or sodium nitrite directly into the stomach, which resulted in elevated plasma nitrate concentrations. As mentioned, in humans, the most important chemical step of this "circulation" is nitrate uptake by the salivary glands, followed by reduction via commensal facultative anaerobic bacteria. In rats, nitrate-reducing bacteria was similarly found on rat tongue, with bacterial density increasing in the direction of the posterior tongue ( $\mathrm{Li}$ 1997). Interestingly, Hyde et al. (2014) showed that supplementation with nitrate in a high amount ( $1 \mathrm{~g} / \mathrm{l})$ for 7 days in drinking water resulted in a substantial decrease in blood pressure and changes in rat tongue bacterial flora. These changes included a significant increase in nitrate-reducing taxas, for example, Haemophilus parainfluenzae, Granulicatella, and Aggregatibacter. Accordingly, it seems that high nitrate diets may induce changes in the oral microbiome, so as to more efficiently reduce nitrate to nitrite and NO (Hyde 2014). These results are in line with our studies showing that nitrate administered for 10 days at a dose of $0.17 \mathrm{mmol} / \mathrm{kg}$ daily decreased thrombus weight to $65 \%$ of control $(p<0.05)$ (Kramkowski 2013). However, as demonstrated in the present work, short-term 3-day supplementation with nitrate $(0.17 \mathrm{mmol} / \mathrm{kg})$ was not sufficient to induce NO-dependent pharmacological effects, most likely because the microbacterial flora of the rats and mice used in our experiments could not sufficiently reduce nitrate to nitrite.

It was recently demonstrated that long-term supplementation of drinking water with dietary nitrate reduced stress-induced gastric damage in the bilateral parotid and submandibular gland duct ligature in rats (BPSDL) (Jin 2013). That ligature completely blocked nitrate secretion by the salivary glands, resulting in decreased gastric nitrate $(60 \%)$, nitrite $(66 \%)$, and NO $(62 \%)$ concentrations. After nitrate supplementation in the drinking water for 1 week, the nitrate and nitrite levels in the fasting gastric juice increased. A similar pattern was observed for the level of luminal NO, which was increased by $1000 \%$. Most importantly, administration of nitrate significantly reduced stress-induced gastric ulcers in BPSDL rats, supporting the notion that the protective effect of nitrate in rats involves enterosalivary circulation. However, nitrate conversion into nitrite through the enterosalivary circulation system seems to require a long period of nitrate exposure to induce the ecological selection of nitrate-consuming bacteria in the gavage. This condition might not be present in the experimental rats or mice fed a standard laboratory animal diet and kept in sterile environment in animal house.

In summary, we have confirmed that nitrite induces profound NO-dependent antithrombotic effects in vivo in mice and rats. However, the conversion of nitrates to nitrite in rats and mice upon short-term 3-day treatment was not sufficient to elicit NO-dependent antiplatelet and antithrombotic effects. This is most likely due to less efficient enterosalivary circulation and sparse microbacterial flora to reduce nitrate to nitrite in rats and mice as opposed to humans, in whom acute NOdependent effects of nitrate have been demonstrated (Kapil 2013).

Acknowledgments This work was supported by the European Union through the resources of the European Regional Development Fund under the Innovative Economy Programme (grant coordinated by JCET-UJ, No. POIG.01.01.02-00-069/09) and by statute grants from the Medical University of Bialystok (nos. 123-26924F and 153-26600F).

\section{Compliance with ethical standards}

Conflict of interest The authors report no conflicts of interest.

Open Access This article is distributed under the terms of the Creative Commons Attribution 4.0 International License (http:// creativecommons.org/licenses/by/4.0/), which permits unrestricted use, distribution, and reproduction in any medium, provided you give 
appropriate credit to the original author(s) and the source, provide a link to the Creative Commons license, and indicate if changes were made.

\section{References}

Bouaziz-Ketata H, Salah GB, Salah HB, Marrekchi R, Jamoussi K, Boudawara T, Fakhfekh F, Zeghal N (2014) Nitrate-induced biochemical and histopathological changes in the liver of rats: ameliorative effect of Hyparrhenia hirta. Biomed Environ Sci 27:695-706

Bryan NS (2006) Nitrite in nitric oxide biology: cause or consequence? A systems-based review. Free Radic Biol Med 41:691-701

Buczko W, Mogielnicki A, Kramkowski K, Chabielska E (2003) Aspirin and the fibrinolytic response. Thromb Res 110:331-334

Cantu-Medellin N, Kelley EE (2013a) Xanthine oxidoreductasecatalyzed reactive species generation: a process in critical need of reevaluation. Redox Biol 1:353-358

Cantu-Medellin N, Kelley EE (2013b) Xanthine oxidoreductasecatalyzed reduction of nitrite to nitric oxide: insights regarding where, when and how. Nitric Oxide 34:19-26

Carlström M, Liu M, Yang T, Zollbrecht C, Huang L, Peleli M, Borniquel S, Kishikawa H, Hezel M, Persson AE, Weitzberg E, Lundberg JO (2015) Cross-talk between nitrate-nitrite-NO and NO synthase pathways in control of vascular NO homeostasis. Antioxid Redox Signal 23:295-306

Doel JJ, Benjamin N, Hector MP, Rogers M, Allaker RP (2005) Evaluation of bacterial nitrate reduction in the human oral cavity. Eur J Oral Sci 113:14-19

Duncan C, Dougall H, Johnston P, Green S, Brogan R, Leifert C, Smith L, Golden M, Benjamin N (1995) Chemical generation of nitricoxide in the mouth from the enterosalivary circulation of dietary nitrate. Nat Med 1:546-551

Falati S, Gross P, Merrill-Skoloff G, Furie BC, Furie B (2002) Real-time in vivo imaging of platelets, tissue factor and fibrin during arterial thrombus formation in the mouse. Nat Med 8:1175-1181

Giles AR (1987) Guidelines for the use of animals in biomedical research. Thromb Haemost 58:1078-1084

Hayashi T, Mogami H, Murakami Y, Nakamura T, Kanayama N, Konno H, Urano T (2008) Real-time analysis of platelet aggregation and procoagulant activity during thrombus formation in vivo. Pflugers Arch 456:1239-1251

He S, Antovic A, Blombäck M (2001) A simple and rapid laboratory method for determination of haemostasis potential in plasma. II. Modifications for use in routine laboratories and research work. Thromb Res 103:355-361

Hendgen-Cotta UB, Kelm M, Rassaf T (2014) Myoglobin functions in the heart. Free Radic Biol Med 73C:252-259

Huang WC, Ploth DW, Bell PD, Work J, Navar LG (1981) Bilateral renal function responses to converting enzyme inhibitor (SQ 20,881) in two-kidney, one clip Goldblatt hypertensive rats. Hypertension 3: 285-293

Huang Z, Shiva S, Kim-Shapiro DB, Patel RP, Ringwood LA, Irby CE, Huang KT, Ho C, Hogg N, Schechter AN, Gladwin MT (2005) Enzymatic function of hemoglobin as a nitrite reductase that produces NO under allosteric control. J Clin Invest 115:2099-2107

Hyde ER, Luk B, Cron S, Kusic L, McCue T, Bauch T, Kaplan H, Tribble G, Petrosino JF, Bryan NS (2014) Characterization of the rat oral microbiome and the effects of dietary nitrate. Free Radic Biol Med $77: 249-257$

Ishiwata H, Tanimura A, Ishidate M (1975) Studies on in vivo formation of nitroso compounds (III). Food Hyg. Saf Sci 16:89-92

Jayaraman T, Tejero J, Chen BB, Blood AB, Frizzell S, Shapiro C, Tiso M, Hood BL, Wang X, Zhao X, Conrads TP, Mallampalli RK, Gladwin MT (2011) 14-3-3 Binding and phosphorylation of neuroglobin during hypoxia modulate six-to-five heme pocket coordination and rate of nitrite reduction to nitric oxide. J Biol Chem 286:42679-42689

Jiang H, Torregrossa AC, Potts A, Pierini D, Aranke M, Garg HK, Bryan NS (2014) Dietary nitrite improves insulin signaling through GLUT4 translocation. Free Radic Biol Med 67:51-57

Jin L, Qin L, Xia D, Liu X, Fan Z, Zhang C, Gu L, He J, Ambudkar IS, Deng D, Wang S (2013) Active secretion and protective effect of salivary nitrate against stress in human volunteers and rats. Free Radic Biol Med 57:61-67

Kahn MJ, Maley JH, Lasker GF, Kadowitz PJ (2013) Updated role of nitric oxide in disorders of erythrocyte function. Cardiovasc Hematol Disord Drug Targets 13:83-87

Kapil V, Milsom AB, Okorie M, Maleki-Toyserkani S, Akram F, Rehman F, Arghandawi S, Pearl V, Benjamin N, Loukogeorgakis S, Macallister R, Hobbs AJ, Webb AJ, Ahluwalia A (2010) Inorganic nitrate supplementation lowers blood pressure in humans: role for nitrite-derived NO. Hypertension 56:274-281

Kapil V, Haydar SM, Pearl V, Lundberg JO, Weitzberg E, Ahluwalia A (2013) Physiological role for nitrate-reducing oral bacteria in blood pressure control. Free Radic Biol Med 55:93-100

Kortboyer JM, Colbers EPH, Vaessen HAMG, Groen K, Zeilmaker MJ, Slob W, Speilers GJA, Meulenbelt J (1994) A pilot-study to investigate nitrate and nitrite kinetics in healthy volunteers with normal and artificially increased gastric $\mathrm{pH}$ after sodium nitrate ingestion. In: International Workshop on Health Aspects of Nitrate and Its Metabolites (Particularly Nitrite). Bilthoven: Council of Europe Press 1994:269-284.

Kramkowski K, Mogielnicki A, Leszczynska A, Buczko W (2010) Angiotensin-(1-9), the product of angiotensin I conversion in platelets, enhances arterial thrombosis in rats. J Physiol Pharmacol 61: 317-324

Kramkowski K, Leszczynska A, Mogielnicki A, Chlopicki S, Fedorowicz A, Grochal E, Mann B, Brzoska T, Urano T, Motterlini R, Buczko W (2012) Antithrombotic properties of water-soluble carbon monoxide-releasing molecules. Arterioscler Thromb Vasc Biol 32:2149-2157

Kramkowski K, Leszczyńska A, Przyborowski K, Buczko W, Chłopicki S (2013) Different effects of nitrate and nitrite on hemostasis in rats. Pharmacological Reports 65, suppl, 57-58. XVIIIth International Congress of the Polish Pharmacological Society, Kazimierz Dolny, 23-25 May 2013.

Kramkowski K, Leszczynska A, Przyborowski K, Kaminski T, Rykaczewska U, Sitek B, Zakrzewska A, Proniewski B, Smolenski RT, Chabielska E, Buczko W, Chlopicki S (2015) Role of xanthine oxidoreductase in the anti-thrombotic effects of nitrite in rats in vivo. Platelets 16:1-9

Larsen FJ, Ekblom B, Sahlin K, Lundberg JO, Weitzberg E (2006) Effects of dietary nitrate on blood pressure in healthy volunteers. N Engl J Med 355:2792-2793

Larsen FJ, Schiffer TA, Borniquel S, Sahlin K, Ekblom B, Lundberg JO, Weitzberg E (2011) Dietary inorganic nitrate improves mitochondrial efficiency in humans. Cell Metab 13:149-159

Laustiola KE, Vuorinen P, Pörsti I, Metsä-Ketelä T, Manninen V, Vapaatalo H (1991) Exogenous GTP enhances the effects of sodium nitrite on cyclic GMP accumulation, vascular smooth muscle relaxation and platelet aggregation. Pharmacol Toxicol 68:60-63

Li H, Duncan C, Townend J, Killham K, Smith LM, Johnston P, Dykhuizen R, Kelly D, Golden M, Benjamin N, Leifert C (1997) Nitrate-reducing bacteria on rat tongues. Appl Environ Microbiol 63:924-930

Li H, Kundu TK, Zweier JL (2009) Characterization of the magnitude and mechanism of aldehyde oxidase-mediated nitric oxide production from nitrite. J Biol Chem 284:33850-33858 
Lundberg JO, Govoni M (2004) Inorganic nitrate is a possible source for systemic generation of nitric oxide. Free Radic Biol Med 37:395400

Lundberg JO, Weitzberg E (2010) NO-synthase independent NO generation in mammals. Biochem Biophys Res Commun 396:39-45 Review

Millar TM, Stevens CR, Benjamin N, Eisenthal R, Harrison R, Blake DR (1998). Xanthine oxidoreductase catalyses the reduction of nitrates and nitrite to nitric oxide under hypoxic conditions.

Mills CE, Khatri J, Maskell P, Odongerel C, Webb AJ (2016) It is rocket science - why dietary nitrate is hard to beet! Part II: further mechanisms and therapeutic potential of the nitrate-nitrite-NO pathway. $\mathrm{Br}$ J Clin Pharmacol. doi:10.1111/bcp.12918

Okabe M, Ikawa M, Kominami K, Nakanishi T, Nishimune Y (1997) Green mice' as a source of ubiquitous green cells. FEBS Lett 407: 313-319

Proulle V, Furie RA, Merrill-Skoloff G, Furie BC, Furie B (2014) Platelets are required for enhanced activation of the endothelium and fibrinogen in a mouse thrombosis model of APS. Blood 124: $611-622$

Qin L, Liu X, Sun Q, Fan Z, Xia D, Ding G, Ong HL, Adams D, Gahl WA, Zheng C, Qi S, Jin L, Zhang C, Gu L, He J, Deng D, Ambudkar IS, Wang S (2012) Sialin (SLC17A5) functions as a nitrate transporter in the plasma membrane. Proc Natl Acad Sci U S A 109: 13434-13239

Roberts LD, Ashmore T, Kotwica AO, Murfitt SA, Fernandez BO, Feelisch M, Murray AJ, Griffin JL (2015) Inorganic nitrate promotes the browning of white adipose tissue through the nitratenitrite-nitric oxide pathway. Diabetes 64:471-484
Sparacino-Watkins CE, Tejero J, Sun B, Gauthier MC, Thomas J, Ragireddy V, Merchant BA, Wang J, Azarov I, Basu P, Gladwin MT (2014) Nitrite reductase and nitric-oxide synthase activity of the mitochondrial molybdopterin enzymes mARC1 and mARC2. J Biol Chem 289:10345-10358

Spiegelhalder B, Eisenbrand G, Preussmann R (1976) Influence of dietary nitrate on nitrite content of human saliva: possible relevance to in vivo formation of $\mathrm{N}$-nitroso compounds. Food Cosmet Toxicol 14:545-548

Tannenbaum SR, Sinskey AJ, Weisman M, Bishop W (1974) Nitrite in human saliva: its possible relationship to nitrosamine formation. $\mathrm{J}$ Natl Cancer Inst 53:79-84

Tannenbaum SR, Weisman M, Fett D (1976) The effect of nitrate intake on nitrite formation in human saliva. Food Cosmet Toxicol 14:549-552

Wang J, Krizowski S, Fischer-Schrader K, Niks D, Tejero J, SparacinoWatkins C, Wang L, Ragireddy V, Frizzell S, Kelley EE, Zhang Y, Basu P, Hille R, Schwarz G, Gladwin MT (2010) Novel function of sulfite oxidase as a nitrite reductase that generates nitric oxide. Free Rad Biol Med 49:S122

Webb AJ, Patel N, Loukogeorgakis S, Okorie M, Aboud Z, Misra S, Rashid R, Miall P, Deanfield J, Benjamin N, MacAllister R, Hobbs AJ, Ahluwalia A (2008) Acute blood pressure lowering, vasoprotective, and antiplatelet properties of dietary nitrate via bioconversion to nitrite. Hypertension 51:784-790

Zand J, Lanza F, Garg HK, Bryan NS (2011) All-natural nitrite and nitrate containing dietary supplement promotes nitric oxide production and reduces triglycerides in humans. Nutr Res 31:262-269

Zatz R (1990) A low cost tail-cuff method for the estimation of mean arterial pressure in conscious rats. Lab Anim Sci 40:198-201 